\title{
700 YEARS OF SETTLEMENT AND BUILDING HISTORY IN THE LÖTSGHENTAL, SWITZERLAND
}

\author{
With 5 figures, 3 photos and 1 supplement (II) \\ Ulf Büntgen, Ignaz Bellwald, Hans Kalbermatten, Martin Schmidhalter, \\ David C. Frank, Henning Freund, Werner Bellwald, Burkhard Neuwirth, \\ MARCUs Nüsser and JAN EsPer
}

\begin{abstract}
Zusammenfassung: 700 Jahre Siedlungs- und Baugeschichte im Lötschental, Schweiz
Alle 2.317 gegenwärtig im Lötschental existierenden Gebäude wurden inventarisiert, zeitlich eingeordnet und kartiert. 1.432 von diesen Gebäuden konnten mit Hilfe von Inschriften, Jahrringen und/oder Archivdokumenten jahrgenau datiert werden. 885 Gebäude wurden durch Schätzungen zeitlich in Jahrhunderte eingeordnet. Diese Datierungen dienen als Grundlage für die Erstellung einer Karte, welche erstmals die Gebäudealter eines gesamten alpinen Tales im Überblick darstellt. In der Karte, welche als Ergebnis einer interdisziplinären Untersuchung unter Einbeziehung lokaler Wissenssysteme und Bezeichnungen verstanden werden muss, werden sowohl Wohn- als auch Wirtschaftsgebäude integriert. Zusätzlich wurden 116 lokale Flurnamen aufgenommen und die Gebäudealter zurück bis AD 1299 in einem Histogramm dargestellt.

Die Zusammenarbeit von Historikern, Volkskundlern und Geographen sowie die aus den jahrgenauen Datierungen gewonnenen Erkenntnisse zu geschichtlichen Bauformen und Konstruktionstechniken ermöglichten die zeitliche Einordnung von Objekten. In diesem begleitenden Text beschreiben wir die Datierungsmethoden, wesentliche Bautypen und Konstruktionstechniken und diskutieren alte Siedlungsmuster und ausgewählte Gebäude. Die Ergebnisse werden unter Berücksichtigung des Kulturlandschaftswandels und der die siedlungsgeschichtlichen Entwicklungen steuernden Faktoren wie Lawinen, Dorfbränden und sozioökonomischen Prozessen diskutiert.
\end{abstract}

Summary: All 2,317 current buildings within the Lötschental were registered, chronologically assigned and mapped. Annual construction dates of 1,432 of these objects based on inscriptions, tree-ring dating and/or documentary evidence were derived. Century-resolved construction dates for the remaining 885 buildings were estimated. These dates are utilized to develop a map that, for the first time, provides a full inventory of building ages of an entire alpine valley. Residential and non-residential buildings are shown in a map resulting from an interdisciplinary study, using local knowledge and nomenclature as a basis. Additionally, 116 local area names were added, and the age of all buildings back to AD 1299 graphically displayed.

The joint analysis by historians, social anthropologists and geographers, as well as the knowledge about historic building types and construction techniques derived from the annual dating, allowed the age estimation of buildings. In this supplementary text, we describe the applied dating methods, some relevant building types and construction techniques and discuss former settlement patterns and selected buildings. We also address some factors of cultural landscape transformation relevant for the settlement history, such as avalanches, fire outbreaks and socio-economic processes.

\section{Introduction}

Landscapes are dynamic patterns of natural and man-made units that vary in size, shape, arrangement, and their degree of human creation (e.g. TURNER et al. 1996). Progress has been made in understanding their changes through time (e.g. TuRner 1990), with many studies focusing on various aspects of cultural landscape transformation in mountainous regions (e.g. BÄtzing 1993, 2003; Byers 2000; DitTMAnN a. NÜSSER 2002; EhLERS a. KREUTZMANN 2000; KIENAST 1993; Krausmann et al. 2003; Mathieu 2003; Nüsser 2001; Olssin et al. 2000; PArmenter et al. 2003; Uhlig 1995; Winiger 1996; Winiger a. Börst 2003). However, explanations for the observed transformation processes remain controversial (e.g. LAMBIN et al. 2001; Turner et al. 1994). Even though, land use and land cover change is a key issue in global change research (IPCC 2000), only a few studies have attempted to understand and quantify longer-term landscape changes (overview in HABERL et al. 2001). One must know that land use change describes a shift in usage, intensification and/or abatement of existing land use, whereas land cover change refers to the conversion and/or modification of the physical state of the land (Turner a. Meyer 1994). Since both components are interrelated, the understanding of landscape transformation should combine assessments of both land use and land cover change (Nüsser 2000). Landscape sustainability, which involves the interaction between physical landscape resources and societal (needs/uses), reflects an additional social aspect of the landscape (BuCHECKer et al. 2003). 
Here we present a local case study from the Lötschental, with observed transformation processes including social and natural factors. These are regarded as being generally representative for other high altitude valleys (FurRer 2003b). Existing data are compiled and new data generated, and synthesized in a map showing the entire valley (Suppl. II). A multi-methodological approach, including tree-ring dating, the interpretation of documentary archives, their cartographic illustration, and the differing perspectives offered by historians, social anthropologists and geographers, allows to fully document and partly interpret the valley's current state of settlement and building patterns. Details of century long wood constructions and building techniques are further provided. To better understand the mapped snapshot of the cultural landscape, past transformation processes are discussed. These include centennial-scale landscape changes, likely reflecting shifts in economic, political and social structures (BeLlwald et al. 1998; LAMBIN et al. 2001; TuRner et al. 1996), climatic variability (BÜNTGEN et al. 2005b; De Menocal 2001; Haug et al. 2003; Magny 2004; MAISE 1998; TinNer et al. 2003), and the most recent socio-economic transformation process including effects of tourism (BäTZING 1993, 1996, 2003; HUNZIKER a. Kienast 1999; Krausmann et al. 2003; LichtenBERGER 1979). Results compile impacts of natural and man-made hazards, such as avalanches, floods, and fire outbreaks (BELLWALD 2000; BRÁZDIL et al. 2005; KeILER et al. 2005; Pfister 1999). Local area names reflecting common indigenous linguistic denotation of parcels and larger areas of forest and/or grassland, are additionally mapped, and provide evidence of a social construction of landscape. ${ }^{1)}$

The paper is structured as regional aspects and the historical development are introduced, and dating methods described. Results are provided, including an overview of the map development. The new map shows century-resolved construction dates of all residential and non-residential buildings. Permanently inhabited buildings that are located within the valley bottom are herein referred to as residential houses, whereas constantly uninhabited buildings either within or outside permanent settlement patterns commonly used for storage are referred to as non-residential houses. The map includes insets, depicting three villages at a higher resolution, and shows their distribution of annually resolved construction dates. Selected

1) Note that except for village names (i.e. Blatten, Ferden, Goppenstein, Kippel, Wiler) all local notations are denoted in italics. results on settlement patterns and building dates are detailed, and construction types and techniques analyzed. Discussion is provided regarding dynamic and persistence of the landscape patterns observed. ${ }^{2}{ }^{2}$

\section{Regional aspects}

The alpine Lötschental is located in the Swiss canton Valais. This dry inner-alpine valley is the largest, and aside from the Leukerbad valley, the only inhabited northern side valley of the alpine Rhône (Fig. 1). It stretches $28 \mathrm{~km}$ along an altitudinal gradient $>2,500 \mathrm{~m}$, from the narrow valley exit in Steg/Gampel $(630 \mathrm{~m}$ a.s.l.) to the Lötschenlücke/Lang-glacier (3,178 m). The elevation of the valley bottom drained by the river Lonza in the mapped study area ranges from 1,230 $\mathrm{m}$ in Goppenstein to 1,900 m east of the Guggistafel. The lower part of the valley is cliffy and its accessibility quite difficult, whereas the upper part becomes wider towards the Lang-glacier (e.g. ОтT 1978). The study area is surrounded by several glaciers and numerous mountain peaks $>3,500 \mathrm{~m}$, with the Bietschhorn $(3,939 \mathrm{~m})$ being the highest. Coniferous forests including European larch (Larix decidua), Norway spruce (Picea abies) and Swiss stone pine (Pinus cembra), timberline ecotones, subalpine grasslands, and avalanche and debris flow tracks on steep slopes are characteristic landscape elements of generally high diversity. Remnant patches of forest, the so-called Bannwald, have been typically preserved above the villages and help protect them against avalanches. Continuous forests reach timberline at about 2,160 m and 2,260 $\mathrm{m}$ on the south and north-facing slopes, respectively. Differences in timberline elevation are rather related to more or less extensive Alp-pasturing than climatic influences (PAUlsen a. KÖRNER 2001). On the south-exposed slopes, mixed larch-spruce forests are widespread, whereas higher reaching larch and pine stands are more common on the north-facing slopes, which are currently void of sub-alpine grasslands (Fischer 1974; LeIBUNDGUT 1938; OTT 1978). Overall larch is the dominant species, reaching maximum tree age of approximately 700 years (BÜNTGEN et al. 2005b). Their long and straight stems and their resistance to weathering, make larch wood an ideal construction timber (BÜNTGEN et al. 2004; SCHWEINGRUBER 2001).

Constrained by the environmental and topographic conditions, the long-term agricultural use of the valley has resulted in a cultural landscape with patterns of dif-

\footnotetext{
2) For a better understanding of terms that commonly reflect more local linguistic usage, see also UHLIG (1995).
} 
fering degrees of human impact, most likely emanating from an early Roman settlement (BÄTZING 2003). Summer pasturing, by moving the main part of the livestock from the permanent settlements in the lowland valley bottom to the mountains for grazing and collection of winter fodder during the short vegetation period, also known as Alp-pasturing, optimizes the sustainable use of the limited biological resources (e.g. BäTZING 2003). For most of the earth's mountain regions, various forms of mixed mountain agriculture (RHOADES a. THOMPSON 1975) are reported (e.g. PRICE 1981; UHLIG 1995). Herein we use the term summer pasturing to describe the temporal movement of livestock (cattle, sheep, goats and horses) from the valley bottom core regions of settlement to higher altitudinal belts. Within the German-speaking part of Switzerland, such high elevation grasslands of temporal utilization are known as Alpe. In the Lötschental, these areas, gained after forest clearing, are commonly located at south-facing slopes between 1,900-2,200 $\mathrm{m}$ and either called Alp (e.g. Faldumalp, Hockenalp, Kummenalp, Lauchernalp, Restialp) or Stafel (e.g. Faflerstafel, Gletscherstafel, Guggistafel, Tellistafel).
The economic dependence on local resources is based on agricultural areas that are mainly concentrated in the upper part of the valley, along the valley bottom, and particularly on the south-facing slopes. The lower section of the valley is unsuitable for spacious settlement and farming. Most residential houses are located near the valley floor, creating clusters of permanent settlement. These sheltered families and their livestock during winter. Depending primarily upon the altitude, temporarily inhabited higher elevation Alp-huts are commonly used during a short period of summer farming and grazing season to accommodate herders and their livestock. Livestock grazing, along with mowing the hay, and the fuel-wood collection, increased alpine grasslands at the expense of natural forests (BACHMANN-VOEGELIN 1984; Risch et al. 2004).

The so-called Maiensässen (e.g. RAGAZ 1991) are a form of temporarily inhabited Alp-huts including nonresidential houses that are located within an altitudinal belt of approximately 1,700-1,900 m, and used during spring and autumn. For the Lötschental, however, these



Fig. 1: 3-D map shows the location of the sub-alpine Lötschental within the canton of Valais in Switzerland (modified after Huber et al. 2003)

Die 3-D-Karte zeigt die Lage des subalpinen Lötschentals im Kanton Wallis und der Schweiz (verändert nach HuBER et al. 2003) 
Maiensässen are usually referred to as Voralpen, and are most commonly pastured during autumn (NiEDERER 1993). The highest-reaching Alp-huts are located at approximately $2,100 \mathrm{~m}$, and were only occupied during six to eight weeks of the high summer, corresponding to the short vegetation period. The contemporary cultural landscape is characterized by numerous nonresidential houses widespread across the valley, most likely reflecting an early Roman influence (BäTZING 2003). However, during the last 30 years, the traditional agricultural usage of most buildings significantly shifted towards their utilization by tourism (BäTzING 1993, 1996; HunZIKER et al. 1999; LiCHTENBERGER 1979).

The opening of the Lötschberg tunnel in 1913 connected the valley to an international railway network, significantly supporting the 'rural-to-urban' transfer of labour (e.g. GRÖTZBACH 1984). From the station at Goppenstein, a road first connected Ferden, and between 1918-20 was extended to Kippel, and in 1954 to Blatten. In 1972, a cable car to the Lauchernalp was constructed, starting extensive ski-tourism, with a further extension of ski-slopes in 2003. However, for the Lötschental, as for the whole alpine region, first tourism is reported since the 1840s (e.g. BACHMANN-VOEGELIN 1984; BÄtzing 1996; Lichtenberger 1979; Siegen 1990; STEBLER 1921). For a more general overview on the man-biosphere system in the European Alps particularly focusing on the most recent tourism trend, we refer to BÄtZing (2003) and Niederer (1993).

To date, the Lötschental provides a large assemblage of old wooden buildings and a substantial collection of historical records (BELLWALD et al. 1996, 1998). Considerable work has been done to collect and interpret settlement and building history data, but most studies have focused on the tabulation of data for selected villages (e.g. BELLWALD 2000; KALBERMATTEN a. KALBERMATTEN 1997). According to archeological findings, evidence of continuous settlement since the Roman time exists. Earlier land use phases of other regions in the Alps were probably related to periods of warmer climate (Magny 2004; Maise 1998; Tinner et al. 2003). For the Lötschental, increasing population numbers are first reported for the high medieval times (BELLWALD et al. 1998). In 1798, a total of 783 inhabitants were registered, with a slight population decrease in the following decades. In 1900, 999 people inhabited the valley (ANNELER 1917). After a slight increase during the last century, the current population of about 1,500 people is distributed among the four communes, Wiler (488 inhabitants), Kippel (368 inhabitants), Ferden (286 inhabitants) and Blatten (281 inhabitants) (KANTON WALLIS 2003).

\section{Methods}

Various sources (i.e., inscriptions, documentary archives, tree-rings, adornments/friezes, building and wood structure), and differing methods (i.e., dendrochronological dating and age estimations) were used to date all buildings in the Lötschental. Buildings are herein defined as structures containing a roof. Dates that derived from carved inscriptions and written documents, as well as from the application of tree-ring dating are regarded as annually resolved. Even though, methods of estimation typically result in inter-annual to multi-decadal precision, they were conservatively assigned to a century-resolution. For all objects only the oldest construction date for the current location is reported and finally mapped (Suppl. II).

\subsection{Inscriptions and documents}

Construction years of most of the annually dated buildings are derived from inscriptions that are generally located outside on the gable. The gable describes a building's triangle front surface below the roof, commonly slope- or valley-aligned (ANDEREGG 2000; Kalbermatten a. Kalbermatten 1997). Several smaller Alp-huts and a few non-residential houses also contain inscriptions engraved on internal beams. In the Lötschental, earliest inscriptions are known from approximately AD 1500 (SIEGEN 1990), and are still regularly applied to new buildings. Historic engravings were deciphered and provide reliable dating, carpenter, and ownership information.

For the upper part of the valley, an update of the Blatten inventory, including metadata from 820 buildings was herein applied (KALBERMATTEN a. KALBERMATTEN 1997). For the middle and lower part of the Lötschental, unpublished communal and private archives, plus results from field inspections and oral interviews, were utilized.

Documentary evidence was used to verify inscription dates. Due to possible translocation facilitated by simple and loose timber constructions, annually precise construction dates do not always reflect the construction date at an object's current location. Efforts to cope with potential disasters resulting from natural hazards (e.g. avalanches, debris flows) and/or socio-economic processes (e.g. population de-/increases, settlement abandonment) led to the translocation of buildings to vantage sites (BELLWALD et al. 1998). These translocations were often registered in documentary archives and were, if available, considered. Younger inscriptions that refer to later modification periods have been disregarded. For all buildings with clearly legible inscriptions 
that refer to the initial construction at the current location, no further dating method was applied. Inexact dates obtained from documentary archives and historical inventories are classified as estimates (see section 3.3).

\subsection{Tree-ring dating}

Dating: For selected buildings of historical relevance that do not possess annually resolved inscriptions, dendrochronological dating methods were applied (FRITTS 1976; SchWEINGRUBER 1996). Tree-ring width measurements from living trees and historic timbers were utilized to date historical buildings, through a method referred to as 'cross-dating' (DougLass 1929).

The first principle of this method relies on the existence of a common underlying climatic signal, influencing tree growth. This signal, here predominantly summer temperature variations (BÜNTGEN et al. 2005 b, 2006; Neuwirth et al. 2004; Treydte et al. 2001), causes synchronous growth variations in all trees living at the same time. Resulting characteristic sequences of wide and narrow rings are utilized to 'wiggle match' sequences from historic timbers with temporally overlapping sequences from living trees, thus allow the dating of historic buildings (e.g. BüNTGEN et al. 2004; WiLsON et al. 2004, 2005).
A total of 341 increment cores were collected, processed, and measured using standard dendrochronological techniques (FRITTS 1976). These cores include 84 samples from living larch trees from locations $>1,750 \mathrm{~m}, 246$ samples from historic larch wood (BüNTGEN et al. 2005b), and 11 samples from historic spruce timbers (BüNTGEN et al. 2005c, Fig. 2). The average growth rate among all samples is $0.8 \mathrm{~mm} / \mathrm{yr}$.

Precise dating of historic construction timbers requires knowledge of the last ring on a wood sample, i.e., the ring that grew in the year of felling. This ring, forming the waney edge (Waldkante), can be identified by the (partial) existence of bark and/or the round shape preserved on untreated timbers. If the waney edge was missing, an estimation of the number of missing rings - from the last ring on a core sample to the missing waney edge - was derived from the number of sapwood rings (SCHMIDT et al. 2001). From the 257 historic samples, 72 include the waney edge, and 166 samples contain sapwood. The latter had an average of 30.2 sapwood rings with a minimum of 3 and a maximum of 60 rings. From samples that did not contain the waney edge, but sapwood, the felling date was estimated by adding $20 \pm 5$ years to the calendar year of the outermost ring.

For a reasonable assessment of the construction date, the number of dated cores per building, which contain

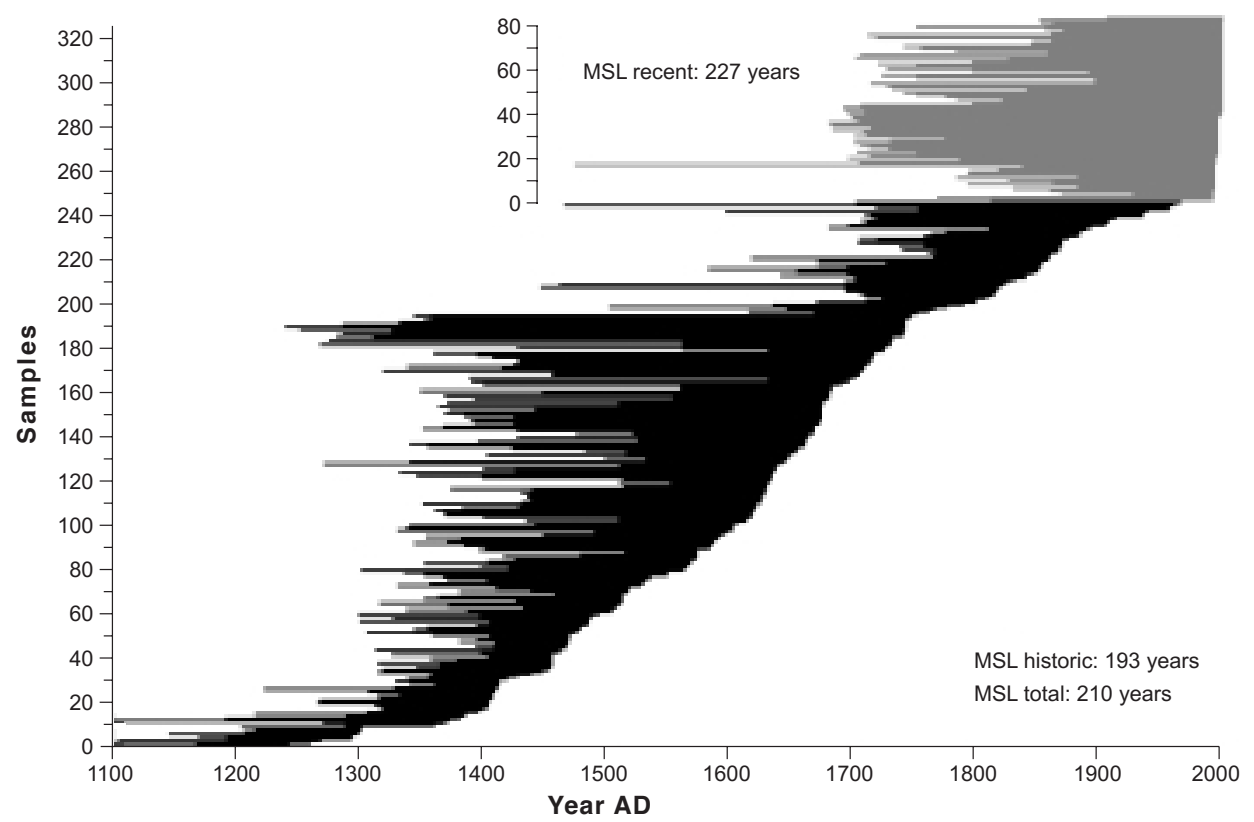

Fig. 2: Sample size and distribution of recent and historic tree-ring width data. Mean segment length (MSL) is the average number of measured rings (years) for recent, historic, and all data

Probenzahl und zeitliche Verteilung von rezenten und historischen Jahrringbreitendaten. Mittlere Segmentlänge (MSL) entspricht der durchschnittlichen Anzahl an gemessenen Jahrringen angegeben für rezente, historische und alle Daten 
more than 60 rings, should range between five and eight. However, the actual number of samples per building necessary to ensure precise dating is related to the building size, architecture, historical metadata background, and the identification and amount of different construction periods. After considering different construction phases and verifying the existence of the waney edge, construction dates were assigned by adding one year to the felling date (SCHMIDT et al. 2001).

Statistical evidence: After 'cross-dating', the program COFECHA (Holmes 1983) was used to detect and correct dating errors. Traditional standardization techniques were applied to remove the biological-induced age trend (FRITTS 1976), and two separate chronologies were developed using the recent and historic samples (Fig. 3A). For detailed growth characteristics of the larch and spruce data see Büntgen et al. (2005a).
Common climatic forcing on inter-annual to decadal scale is indicated by the synchronous behaviour of these records during the 1694-1940 period of overlap $(r=0.88)$. In addition to the climate signal, quasi-periodic (8-9 years) larch budmoth (Zeiraphera diniana) outbreaks (BALTENSWEILER a. RUBLI 1999) were detected, and consequently replaced (ESPER et al. 2006).

Maximum chronology replication of 135 samples is reached in the $15^{\text {th }}$ century (Fig. 3B). The average 'inter-series' correlation (Rbar) was calculated over 50year intervals (lagged by 25 years), using all single measurements (details in WigLEY et al. 1984). Rbar values range from 0.20 to 0.64 with a mean of 0.49 and 0.40 for the recent and historic chronology, respectively (Fig. 3G). The common signal in the living and historic chronologies allowed the development of a single 918-year long time-series (1085-2002), composed of

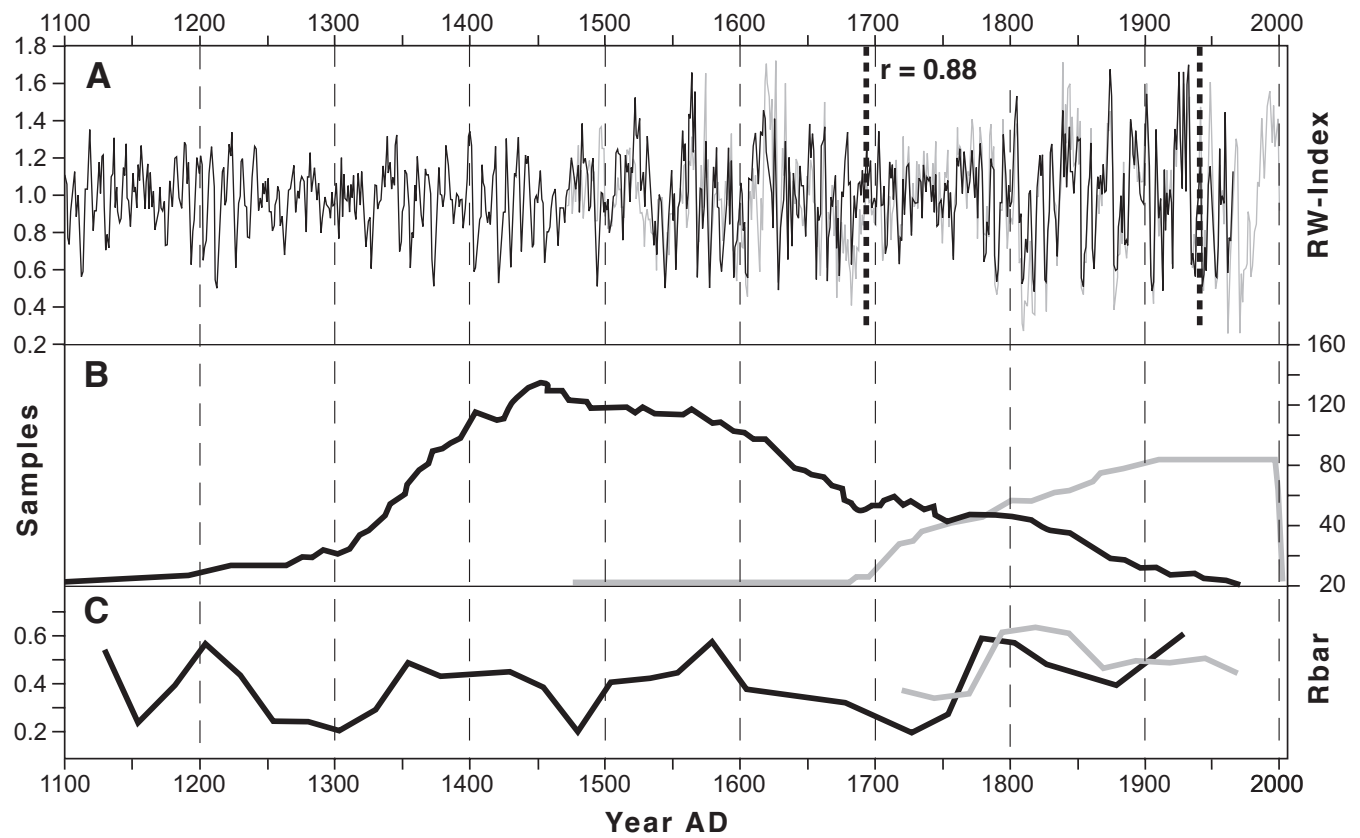

Fig. 3: (A) Comparison of the chronologies from historic (black curve) and recent (grey curve) wood. The chronologies were developed by calculating residuals after power transformation (COOK a. PETERS 1997) from length adaptive spline filters (details in COOK a. PETERs 1981) to emphasize common inter-annual to inter-decadal scale variations (ESPER a. GÄRTNER 2001). Dashed vertical lines highlight the period of overlap (1694-1940) with at least five series averaged in the historic and recent chronologies. Correlation during this period is 0.88. (B) Numbers of historic (black) and recent (grey) samples. (C) Running 'inter-series' correlations (Rbar) of historic (black) and recent (grey) data

(A) Vergleich der Chronologien aus historischem (schwarze Kurve) und rezentem (graue Kurve) Holz. Die Chronologien wurden als Differenz der Originalwerte nach power transformation (COOK a. PETERS 1997) von längenadaptiven Filterfunktionen berechnet (Details in COOK a. PETERS 1981). Diese Standardisierung betont jährliche bis dekadische Variationen (ESPER a. GÄRTNER 2001). Die vertikalen gestrichelten Linien kennzeichnen den gemeinsamen Zeitraum (1694-1940), in dem beide Chronologien aus mindestens fünf Einzelserien gebildet wurden und mit 0.88 korrelieren. (B) Anzahl der historischen (schwarz) und rezenten (grau) Proben. (C) Gleitende 'inter-series' Korrelationen (Rbar) der historischen (schwarz) und rezenten (grau) Daten 
341 series and 71,610 tree-ring measurements. The precise dating of particular late medieval buildings is achieved by the temporal robustness of the chronology, and the climatic signal preserved in the wood samples. Comparison with other regional high elevation larch chronologies (BÜNTGEN et al. 2005b) and the development of a second tree-ring parameter record, i.e., maximum latewood density (BÜNTGEN et al. 2006) provided independent verification for the new Lötschental chronology.

\subsection{Estimations}

Construction dates of all remaining buildings were estimated by a combination of the following evidences: (i) adornments/friezes, (ii) building size, form and fragmentation, (iii) documentary archives, and (iv) wood structure, condition and colour.

(i) Frieze analyses were used to estimate most of the undated houses, some Alp-huts and non-residential houses. A frieze pattern is an adornment often seen as ornament in architecture, repeating in one direction (COXETER 1961). Friezes contain precise dating information as different time periods are characterized by particular patterns (KALBERMATTEN a. KALBERMATTEN 1997; RUPPEN 1976, 1979, 1991). Their location, size, design and complexity all provide temporal evidence. Each carpenter made somewhat unique frieze profiles. Their recurrence in different houses and villages helps track carpenters' operating range and activity. Further information is derived from engraved beams. Temporally evolving carpenter techniques provide additional dating evidence for residential houses of comparable socio-economic value. The effort of carpenters and their techniques are also related to the importance and function of the building. Several examples of fine craftsmanship exist from the $15^{\text {th }}$ and $16^{\text {th }}$ century (Photo 1, 2). Less ostentatious non-residential houses of lower socio-economic value rarely possess complex friezes or display carpenter techniques characteristic for their construction period.

(ii) The size, form and fragmentation of buildings are additional criteria to estimate construction dates (EgLOFF a. EgLOFF-BODMER 1987; KALBERMATTEN a. KALBERMATTEN 1997). Older objects are generally smaller with a more simple construction shape. Surface extent was limited by structural constraints. Oldest buildings in the Lötschental typically have square ground-plans, with square gable facades in the valleyfacing main room and the slope-facing kitchen (Photo 1). An increase in the complexity, e.g. size and number of rooms, and a more asymmetric fragmentation is typical for younger objects (Photo 2).
Layouts provide additional chronological information. In the $15^{\text {th }}$ and $16^{\text {th }}$ century, most houses were composed of a basement, a main room, a kitchen, and a bedroom located directly under the roof. The kitchen was open upto the roof. From approximately AD 1600 onwards, several houses contain partitioning walls to create further rooms. From approximately 1900 onwards, houses with three to four rooms and even duplex houses exist. However, these criteria are only a general guideline. Small single-room buildings were still constructed in the $19^{\text {th }}$ century, and certain houses built at the end of the $16^{\text {th }}$ century were already characterized by 'modern' proportions, e.g. the Feiziner Huis in Ferden, AD 1591 with a facade of eight m length (Photo 2).

Windows and doors from earlier periods were usually smaller, and room-heights lower than today. For the Vogl Huis in Ferden, AD 1532, the original height of the main entrance was $1.27 \mathrm{~m}$, and the windows measured $0.40 \mathrm{~m}$ in height. Even though these early windows and doors have generally been enlarged and replaced by more contemporary constructions, their original size is often still recognizable. Additional evidence derives from extensive friezes, reported from the $16^{\text {th }}$ and $17^{\text {th }}$ century (RUPPEN 1976, 1979, 1991).

For most of the non-residential houses, notable trends in size, form and fragmentation are not recognized throughout the past 700 years (Photo 3). Their dating mainly relies on documentary archives, woodstructure, -condition, -colour, and further construction details.

(iii) Documentary archives, such as cadastral and church registers, genealogical reconstructions, and other written sources, provide detailed chronological information on former settlement and construction activities, as well as information on past environmental conditions (e.g. BRÁZDIL et al. 2005; PFister 1999). These archives further preserve details on former land and building ownership (e.g. TURner et al. 1996). Herein, documentary data that include information on translocation and/or rebuilding were used as metadata (BELLWALD et al. 1998), but disregarded for annually resolved dating purposes.

(iv) Wood structure, condition, and colour were used to further validate building ages. The surface structure of tree-rings indicates timber decomposition due to weathering. Differing densities of late- and earlywood reflect the degree of decomposition and reveal age evidence (SCHWEINGRUBER 2001), with compact and bright wood generally indicating more recent construction dates (SchweIngRuber 1996). The particular darkening of larch timber is completed after almost hundred years. However, exposition and differing treat- 

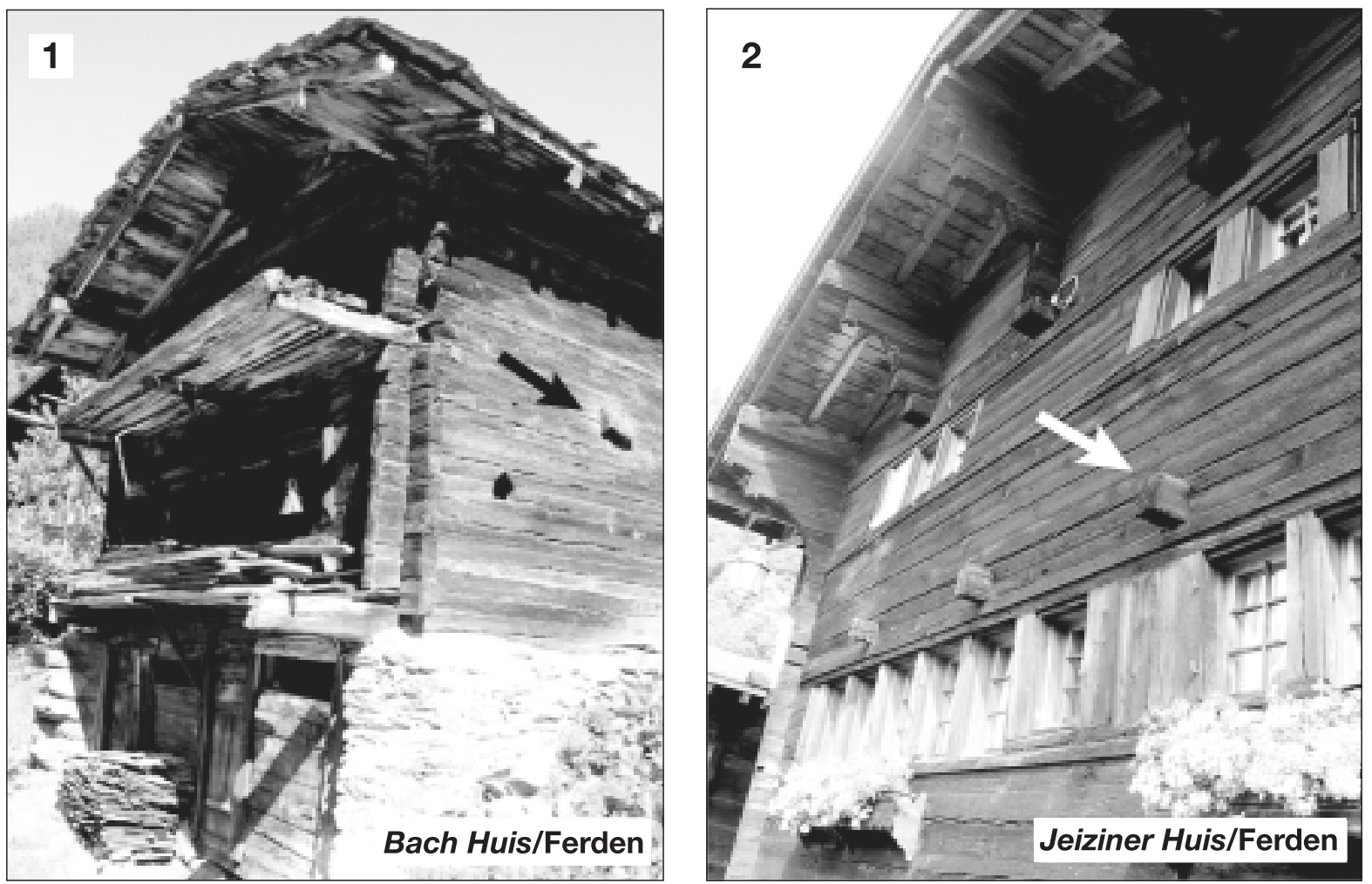

Photos 1, 2: Comparison of the Bach Huis (AD 1502, tree-ring dated) with a ridge-transverse main room beam (black arrow) and the Feiziner Huis (AD 1591, by inscription) with ridge-parallel beams (white arrow). These construction techniques are representative for differing construction periods

Vergleich des Bach Huis (AD 1502, Jahrring-datiert) mit firstquerem Stubenbinder (schwarzer Pfeil) und des Feiziner Huis (AD 1591, Inschrift) mit firstparallelen Bindern (weißer Pfeil). Diese Bautechniken repräsentieren unterschiedliche Konstruktionsperioden

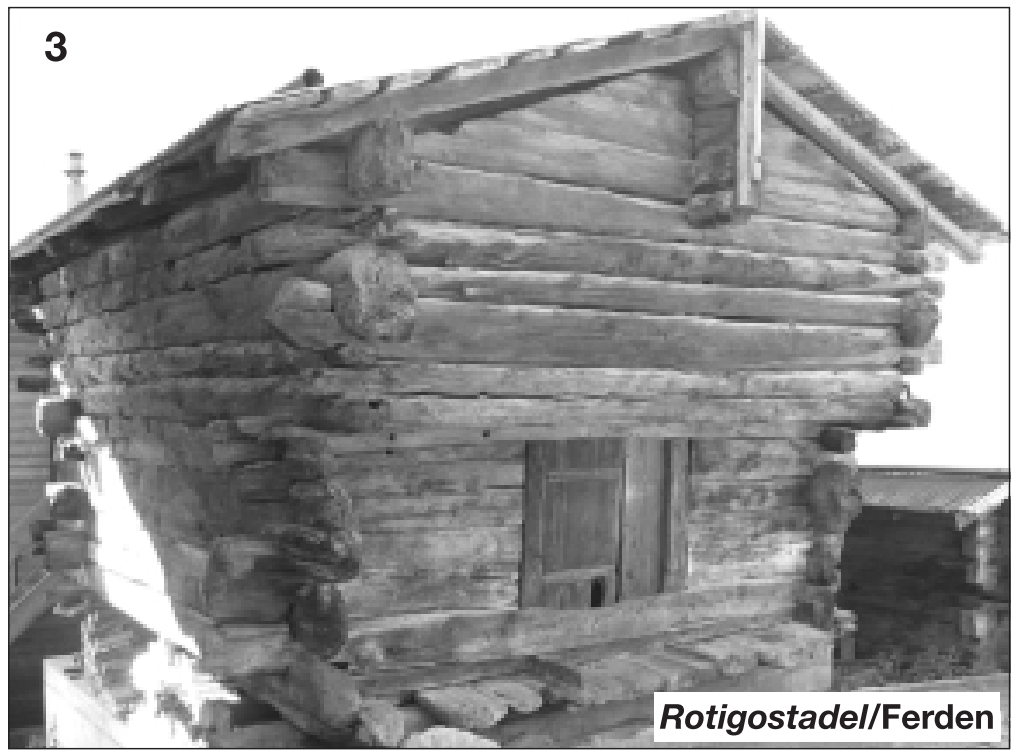

Photo 3: The oldest, originally preserved shed within the Lötschental (Rotigostadel in Ferden, AD 1302)

Der älteste, im Originalzustand erhaltene Speicher innerhalb des Lötschentals (Rotiogostadel in Ferden, AD 1302) 
ment (e.g. painting or glazing) affect this process. Spruce wood tends to maintain the original bright colour over several centuries (Photo 3).

A combination of all dating methods $(i-i v)$ was ideally used to estimate construction dates. This methodological combination gained from independent data and expert exchange of various research fields resulted in construction dates ranging from annual to centennial scale. Non-residential houses of lower socio-economic value - often labelled as 'architecture without architects' - provide less reliable evidence for their construction dates, because of their lack of architectural individuality, and the low evolution of construction techniques over the past centuries.

\subsection{Mapping}

Four digital map-sheets (\#5,285-5,288), developed by SWISSPHOTO and provided by the KANTON WALLIS (2003) were merged to create a high resolution, 1:10,000 base-map, that allows for the precise location of all buildings plus metadata (Suppl. II). To better convey the spatial organization of the cultural landscape, and to demonstrate the social construction of space, 116 local area names were mapped. These indigenous toponyms plotted in black/bold reflect the current denotation and local linguistic usage. Annual construction dates and century-resolved estimates are shown in a histogram (Suppl. II). The three oldest buildings located in Ferden are additionally marked.

Only oldest construction dates of actual location are included. Higher resolution inset maps of Ferden, Kippel and Blatten are shown, with annually dated buildings framed in black. Insets provide details on settlement dynamic, e.g. broadening of the main road in Ferden and Kippel, reorganization of village centres, and preservation, translocation and rebuilding of objects. For example in Tärra, a private open-air museum of historical buildings (W/S/W of Wyssried, 1,685 m), the map shows the rebuilding $20^{\text {th }}$ century dates. In so doing, Tärra is identified as a recent agglomeration of old buildings. The inset map of Blatten provides additional information on the translocation of buildings as circled in red.

\section{$4 \quad$ Results}

\subsection{Construction dates}

The supplementary map compiles 700 years of settlement and building activity in the Lötschental. Nonetheless, today's cultural landscape represents a contemporary snapshot only, it aggregates former socio-economic transformation processes. The current state of land use and land cover most likely results from the long-term interaction between environmental resources, historical processes and socio-economic aspects. These local processes are probably representative for adjoining mountain valleys. The interaction of various methodological approaches obtained annually resolved or century estimated construction dates of all buildings and their spatial dispersal. We herein address (i) the observed spatio-temporal settlement patterns of the valley, and (ii) the four villages of interest.

(i) Settlement patterns: The map shows 2,317 chronologically classified buildings and aggregates settlement and building activities of the last 700 years. 1,432 buildings are annually dated, and 885 are estimated. All buildings range within the altitudinal belt of 1,2302,565 m (Goppenstein-Bietschhornhütte).

1,114 were classified as residential houses, and 1,203 as non-residential houses. Within the group of residential houses, 575 houses, 247 vacation chalets and 292 temporarily inhabited Alp-huts were recorded. Within the group of non-residential houses, 917 included supporting walls, 90 were without supporting walls, and 133 were classified as general economy buildings, such as garages. These numbers clearly depict the economic value of non-residential houses. Most of the residential houses include further space for agricultural usage. A complex ownership structure of most economic buildings yields to a simple multiplication of property dispersal. The high number of vacation chalets, however, describes the late 20th century increase of tourism activity commonly reported for the European Alps (BÄTZING 1996, 2003). The spatial organization of settlement results from an interaction between landscape use and landscape cover.

For the total study area, only 200 buildings are located on the north-exposed slope, south (east) of the Lonz a river, with most of these used for agriculture and located within the valley bottom. Buildings on the south-facing slope exist in different altitudinal belts, reflecting extensive summer pasturing activities. Due to a significant decrease in alpine agriculture and forest management since approximately 1950 (FISCHER 1974; KRAUSMANN et al. 2003; RiscH et al. 2004), numerous non-residential houses have been abandoned, or shifted towards tourism usage (BÄTZING 1996). 63 objects belong to religious institutions. These contain small chapels and churches, and are indicators of a unique sacral landscape with deeply rooted traditions (ANNELER 1917; STEBLER 1907; Weiss 1959).

(ii) Villages: Blatten is the biggest community with altogether 820 buildings within its territorial boundary, 
of which 280 are located in the agglomeration, followed by Wiler $(632 / 270)$, Ferden $(441 / 198)$ and Kippel (424/232). The majority of tree-ring dates derives from Ferden (18 buildings), followed by Kippel (13 buildings), Blatten (6 buildings), and 18 other buildings scattered within the valley.

Ferden has the greatest number of historic objects, including 59 annually dated buildings before 1800 , and 11 objects before 1500 . It also includes the three oldest buildings in the Lötschental: the Brigischiir (AD 1299) southeast of the chapel, the Rotigostadel (AD 1302-1304, Photo 3) in the current village center, and the Ufm Obrin Dorf'schiir (AD 1304) northeast of Ferden. These three economic buildings are tree-ring dated and highlighted in the map. For the Brigischiir and Rotigostadel, modification periods were identified in the $16^{\text {th }}$ and $17^{\text {th }}$ centuries, respectively. Interestingly, the oldest, completely preserved building in the Lötschental, the Rotigostadel, is one of the rare cases where spruce wood was used for construction. Overall, Ferden is characterized by an age-dipole, i.e., oldest buildings exist in the western and eastern parts, but are entirely missing in the current village centre. This pattern most likely results from a debris flow channel, the so-called Steinige Schleif opposing the current village centre.

Kippel contains the most original late medieval settlement structure with several historic buildings and the ancient stone church located in the centre. In its territorial boundary, 54 buildings date prior to 1800 and two before 1500. The oldest house is the Bletschu Huis, tree-ring dated to 1409. Today, the Bletschu Huis is the only preserved late medieval, 'multi-function' house within a continuously settled agglomeration (BELLWALD et al. 1998). Its complex structure results from the original late medieval residential house (AD 1409), providing space for inhabitants, their livestock and agricultural tools, and several more recent modification phases (e.g. 1668-70).

The territorial boundary of Wiler includes 13 objects built before 1800, and only four buildings in the agglomeration were built in the $18^{\text {th }}$ and $19^{\text {th }}$ centuries. One shed is dated to 1614 . The reason for this lack of older buildings was a destructive fire outbreak in 1900 (details in BELLWALD 2000). The majority of the centre was rebuilt within five years after the fire outbreak. Several comparable fire hazards in the Valais occurred during the last millennium (ANTONIETTI 1990). Today, Wiler possesses a less clustered structure, several stone houses, and is the most rapidly growing community. The tourist area Lauchernalp includes 227 buildings and is already bigger than the village of Ferden.

The territorial boundary of Blatten includes 106 annually dated objects before 1800 . The oldest house that is located in Wyssried, dates to 1455, and the oldest building in the village dates to 1516. For Blatten, we exclusively provide information of past translocation processes, since 11 buildings within the agglomeration derive from different locations (details in KALBERMATTEN a. KALBERMATTEN 1997).

For each village, except for Wiler, a significant age decrease of several hundred years, away from the village centre outwards is evident. The majority of more recent buildings uses more floor space and often approaches steep terrain, characterized by avalanche and debris flow tracks. Oldest buildings are generally located near former easily accessible and constant water supplies.

\subsection{Construction types}

The inventory further provides information on construction types and techniques and their temporal evolution. Of particular interest is the spatio-temporal distribution of 33 remaining late medieval residential houses (ANNELER 1917; Siegen 1990; STEbler 1907, 1921). These are characterized by a ridge-transverse main room beam (Photo 1), locally called Dielbaum (Ruppen 1976, 1979, 1991, Fig. 4). Since this late medieval construction technique used only one horizontal main beam perpendicular to the ridging, and crossing the main room, the so-called Firstquerer Stubenbinder, it was commonly applied for smaller buildings. Inscriptions and tree-ring dating provide annual construction dates of 13 of these objects, either in original or modified conditions, ranging between AD 1411-1545 (Fig. 4). For the remaining 20 buildings, construction dates were estimated for the $15^{\text {th }}$ and the first half of the $16^{\text {th }}$ century. These house types usually contain about 20 square meters. Beams (Firstquere Stubenbinder) extending one to two meters outside the building were commonly used as additional roofing and/or to hold stairs. We believe this to be the oldest house type still existing in the Lötschental, if not in the Valais. The end of this particular late medieval construction type was related to structural requirements of increasing house sizes within the $16^{\text {th }}$ century (Photo 2).

A further construction type, the Heiden Huis (STEBLER $1907,1921)$ that is highlighted by one or more crosses within the gables and a single ridge pillar construction, locally called Freistehender Firstständer was analyzed (RUPPEN 1976, 1991). This early construction type is characterized by its simple free-standing pillar carrying a main horizontal beam. Since only a few Heiden Huiser are preserved in the Lötschental, several of them still exist in the village of Mühlebach, Goms/Valais (FurRER 2003a; RupPen 1979). These buildings had economic functions and were constructed from round or semi- 
round timbers (Halbrundholz), e.g. the Heidenschiir in Kipple. Their construction period is not clearly defined; however, dates for Mühlebach range from AD 1381-1497.

Overall, the construction types were/are closely related to the buildings' function and deemed importance. For expensive residential houses, complex construction techniques were already used during late medieval times. These buildings are witnesses to an increased $17^{\text {th }}$ century economic wealth of the local population, and their living and representation conveniences. For smaller non-residential houses, however, unshaped timbers, the so-called Rundlinge are still used.

The oldest buildings in the Lötschental (Brigischiir, Rotigostadel, Ufm Obrin Dorf'schiir) are key in understanding the regional transition of construction techniques using round timbers (Rundlinge) to the utilization of shaped scantling beams (Blockholz). The oldest building in the Valais (Heiden Huis in Mühlebach/Goms) that shows only shaped scantling beams, dates to 1381 . The three houses in the Lötschental (1299-1304) used partially shaped beams, are thus the oldest known examples of semi-round beam constructions. These may represent a transitional form between the scantling construction technique and earlier techniques using only round, unshaped beams (Simplon, AD 1200). The temporal evolution of differing construction types is likely to be comparable with other alpine valleys, since distinct cultural exchange occurred (ANDEREGG 1996; FURRER 2003b).

\section{Discussion}

\subsection{Settlement and building dynamics}

Landscape transformation occurs through (i) longerterm processes, and/or (ii) extreme events, with both being triggered by natural and/or anthropogenic system shifts with complex interactions.

(i) Low frequency climatic variability, and long-term socio-economic processes can impact upon settlement patterns. Periods of differing climatic conditions, e.g. the putative Medieval Warm Period (Lamb 1965), the so-called Little Ice Age (GROVE 1988), and the recent warmth (BÜNTGEN et al. 2005b, 2006), caused environmental changes on multi-decadal to centennial-scales (e.g. Pfister 1999; Wanner et al. 2000a), with high mountain regions being particularly sensitive (BENISTON 2003). Prominent examples of climatic variability and its impact on human settlement are reported for differing regions and periods of the Holocene (DE Menocal 2001; Haug et al. 2003; Magny 2004;

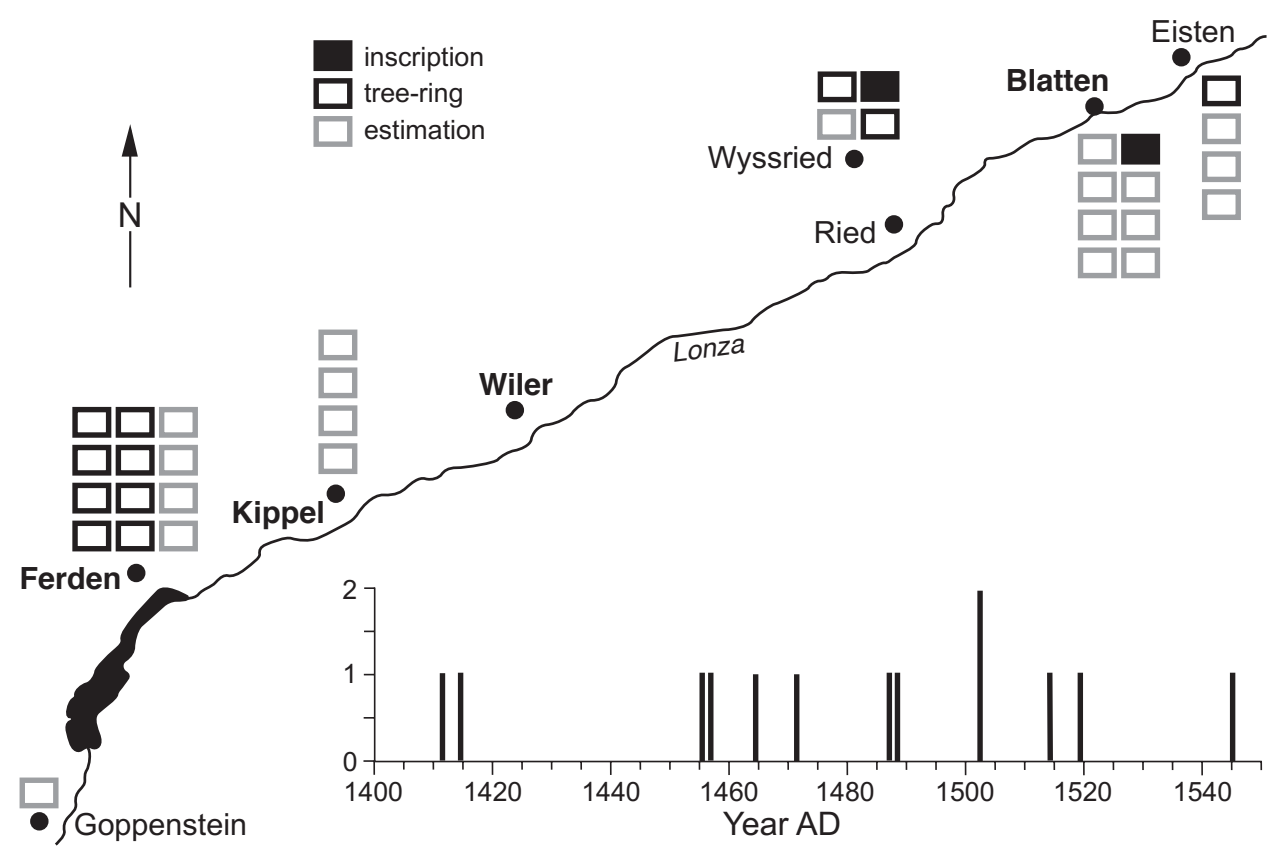

Fig. 4: Draft of the Lötschental showing the location, number and age of preserved late-medieval residential houses with a ridge-transverse main room beam, and their dating method (see symbols at the top of the figure)

Die Skizze des Lötschentals zeigt die Lage, Anzahl und das Alter von spätmittelalterlichen Wohnhäusern mit firstquerem Stubenbinder und ihre Datierungsmethode (siehe Symbole oben in der Figur) 
TINNER et al. 2003). Long-term climatic variations are likely to impact upon the growing season length, land use intensity, agricultural productivity rate, health conditions, the frequency of avalanche occurrence, and the extent of glacier advance and retreats (e.g. BENISTON 2003; HOLZHAUSER 2002).

Longer-term socio-economic processes transformed settlement patterns, most likely as a reaction to climatic fluctuations, political regimes, technical evolution, and social organization of society (BELLWALD et al. 1998; BitTERLi-WALDVOGEL 1998). Starting from a scattered late medieval settlement space that was characterized by several hamlets within differing altitudinal belts (Stebler 1907, 1921; Siegen 1990), - today's hamlets include residential and non-residential houses commonly located within the valley bottom, e.g. Chiemad, Eisten, Goltschried, Ried, and are either permanently or temporarily inhabited - societal centralization trends followed. Recent buildings are located in agglomerations, only. Benefits of villages are economic, geographic, and psychological. Centralization processes associated with service increase, economic efficiency, social communication and support, have played an important role, today and in the past (LAMBIN et al. 2001). The most recent desertion process, that started during the second half of the $20^{\text {th }}$ century, is caused by a significant reduction in agricultural usage of land and buildings (BätZING 1993; KRAUSMANN et al. 2003). This transformation, as well as a complex ownership structure (TURNER et al. 1996), probably destroyed the highest amount of late medieval buildings, relative to the past millennium.

Both, natural and anthropogenic transformation processes caused the abandonment of several historic hamlets. The current landscape is characterized by numerous of ruins that are widespread within the valley. Historic settlement remains are found within an altitudinal belt of 2,300-2,500 m, clearly above recent treeline (e.g. OBRECHT et al. 2003). Their location presumably indicates a formerly natural timberline position, thus describing the degree of its current manmade depression (BELLWALD et al. 2006; PAULSEN a.

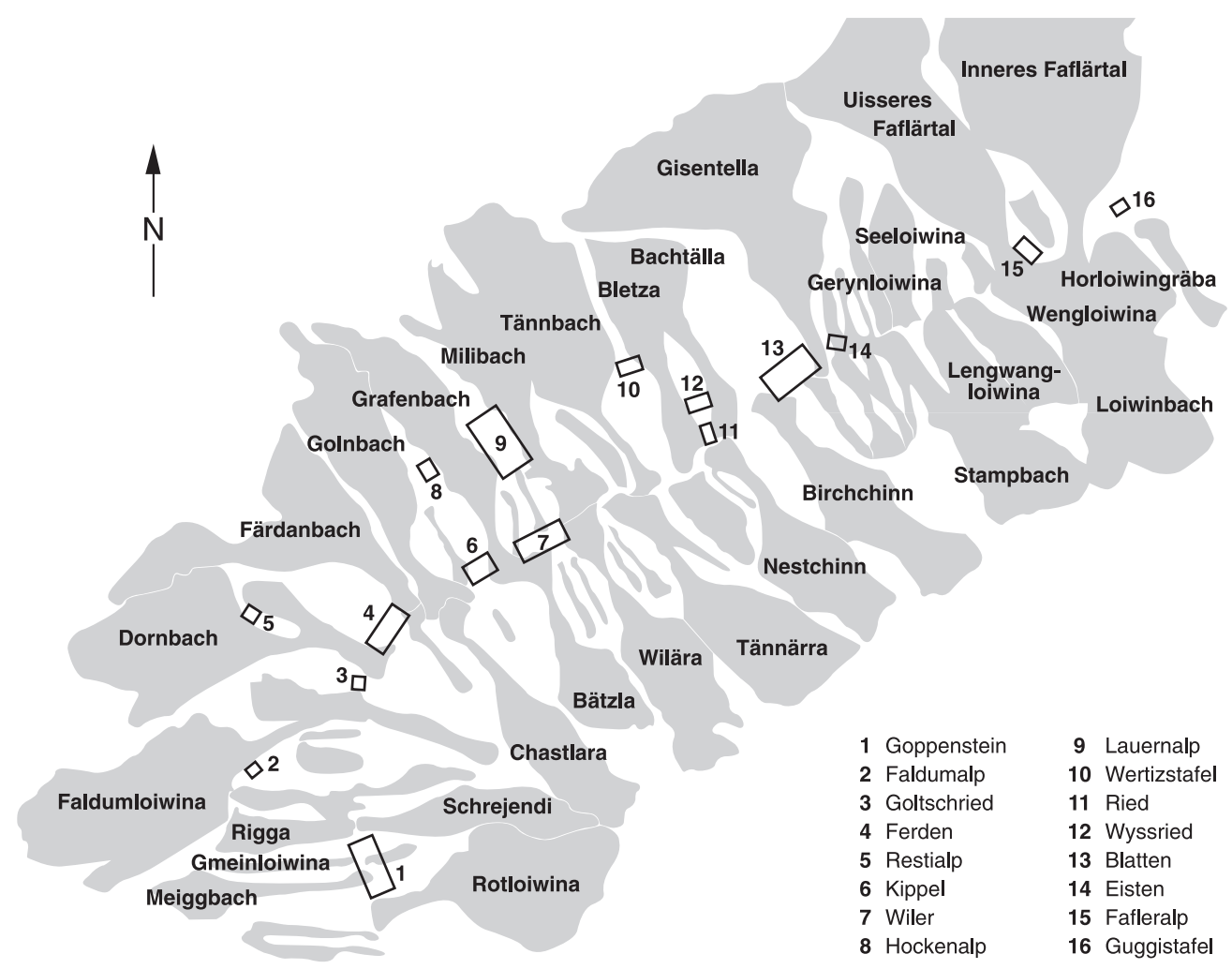

Fig. 5: Draft showing the spatial distribution of the 63 most frequent avalanche tracks within the Lötschental. The 16 most important agglomerations, ranging from villages in the valley bottom to high elevation Alp-pastures are indicated (1-16)

Die Skizze zeigt die räumliche Verteilung der 63 häufigsten Lawinenbahnen im Lötschental. Die 16 wichtigsten Agglomerationen, von den Dörfern im Talboden bis hin zu den Alpen sind angegeben (1-16) 
KÖRNER 2001). The abandonment of land and buildings has resulted in reforestation (KIENAST 1993; RISCH et al. 2004). From an economic point of view, today's high mountain agricultural usage is inefficient; however, it is indispensable for the preservation of cultural landscape, which is highly valuable for the tourism sector (BÄTZING 1993, 1996; BUCHECKER et al. 2003; HunZIKer et al. 1999; KraUSMANN et al. 2003; LichTENBERGER 1979). Reconstructed ancient settlement patterns are witnesses of past population pressure, lower agricultural productivity, periods of climatic disfavour and a generally more decentralized sub-alpine society (BELLWALD et al. 1998; BITTERLI-WALDVOGEL 1998; GRÖTZBACH 1988). We believe that the amount of abandoned ruins widespread within the Lötschental exceeds the number of the mapped buildings (BELLWALD et al. 2006).

(ii) Avalanche events, modulated by particular climatic conditions over the European/North Atlantic sector (RAIBLE et al. 2006; WANNER et al. 2000b), have a significant impact on local- to regional-scale settlement patterns in the Alps (KeILer et al. 2005). For the Lötschental, 30 major and 33 smaller avalanche tracks are recorded (Fig. 5). In 1776, 15 Alp-huts were destroyed on the Gletscherstafel, and rebuilt the following year. The same avalanche destroyed 33 Alp-huts and the chapel in 1937. In the winter of 1951, an avalanche killed six people and destroyed 70 buildings in Eisten (details in KALBERMATTEN a. KALBERMATTEN 1997). In the winter of 1999, avalanches destroyed six buildings in Aalegin, six in Loizinun and one house in Ried. Consequently, a protection dam was built in Ritzmad (east of the Weritzstafel), and a protection wall in the Schteynigsbord (above the Blühendenalp). The intensive utilization of Alp pastures and continuous forest stands can prevent avalanche events (FISCHER 1974). This argument, however, only accounts for smaller avalanches. Back in time, lower financial investments, reduced technical know-how and less innovative construction material, probably increased the impact of natural hazards (e.g. avalanches, floods) on settlement and building patterns (BrÁzdil et al. 2005; Pfister 1999).

Besides natural hazards, man-made fire outbreaks triggered settlement and building patterns. For a detailed description of the destructive fire outbreak in Wiler $\mathrm{AD}$ 1900, including its socio-economic and structural relevance, see Bellwald (2000), and ANTONiETti (1990) for comparable fire hazards within the Valais.

\subsection{Settlement and building persistence}

Apart from the dynamic aspects of landscape transformation, distinct settlement, building, and land use persistence exists in the Lötschental. This landscape persistence is closely related to the economic value of land use and land cover (Turner a. Meyer 1994; TURNER et al. 1994). Since an intensive agricultural use of natural and human resources persisted in the Lötschental for the last two millennia or so, the preservation of buildings was somehow warranted. Comparisons between the cultural persistence of high mountain regions, e.g. Andean-Himalaya-Alps, obtained similar results (MATHIEU 2003; NÜSSER 2000, 2003; WiNIGER a. BÖRST 2003). For the canton of Fribourg, ANDEREGG (1996) reported the persistence of historic buildings; however, the majority derived from the past two centuries, and older buildings became sparse. Specific reasons for landscape conservation within the Lötschental are the relatively long undeveloped tourism sector, the remote location, and the agricultural productivity (BÄTZING 1996; LICHTENBERGER 1979).

In the absence of the natural and anthropogenic extremes outlined above, the mountain environment described, including the socio-economic relevance of the building, as well as an extended winter-snow cover and dry summers, allows for the long-term preservation of timber constructions. The map shows this persistence of late medieval land use and land cover structures including settlement and building patterns that are still characteristic for today's landscape.

\section{Conclusions}

We provide, for the first time, a full inventory of buildings of an entire alpine valley, with their construction dates covering the AD 1299-2004 period. The newly aggregated map and its descriptive text result from an interdisciplinary study heavily depending upon local knowledge and nomenclature, as well as the interaction between differing research fields. Various sources such as inscriptions, documentary archives, tree-rings, adornments/friezes, building and wood structure, and differing methods including dendrochronological dating and age estimations allowed the comprehensive understanding of multicentennial long settlement and building activities within the Lötschental.

2,317 chronologically classified objects, from which 1,114 are classified as residential, and 1,203 as non-residential houses, as well as 116 indigenous toponyms are summarized in a high-resolution map. 1,432 buildings based on inscriptions, tree-ring dating and/or documentary evidence are annually dated. For the remaining 885 buildings, century resolved construction dates 
are estimated. For the total study area, only 200 buildings are located on the north-exposed slope close to the valley bottom. Objects on the south-facing slope, however, range within an altitudinal belt of approximately $1,200-2,200 \mathrm{~m}$

The three oldest buildings in the Lötschental are tree-ring dated between AD 1299-1304. These are key in understanding the transition of construction techniques using round timbers to the utilization of shaped scantling beams. Besides the reconstructed building ages, further information on their construction types and techniques revealed the spatio-temporal distribution of 33 ancient late medieval residential houses, most likely representing the oldest house type still existing in the Valais.

A distinct settlement, building, and land use persistence is proved for the Lötschental. This cultural landscape persistence is closely related to the economic value of land use and land cover. A significant reduction in agricultural usage of land and buildings, starting within the second half of the $20^{\text {th }}$ century, as well as a complex ownership structure, however, likely destroyed the largest amount of late medieval buildings, relative to the past millennium.

Local to alpine-wide factors, such as the Lötschental's indigenous value system and traditions, accessibility and connection to economic pathways, integration in national and international political frameworks, acquisition of financial investments, potential for sociocultural and -economic innovations, and acceptance of sustainable changes are all interrelated and have been crucial for the observed development patterns. Even though many of these factors have undergone a somewhat parallel evolution for most high mountain valleys in the European Alps, the degree to which the reconstructed settlement and building history is representative for adjoining regions remains uncertain.

\section{Acknowledgements}

We thank D. Nievergelt, K. Treydte and A. Verstege for field assistance and discussions. M. Bellwald kindly provided avalanche data, and the Canton Valais cartographic material. We thank the inhabitants of the Lötschental for their hospitality. Supported by the SNSF (NGCR Climate) and the European Community, ALPIMP project (BBW 01.0498-1). U.B. supported by the SNSF project EURO-TRANS (\#200021-105663).
References

AnderegG, J.-P. (1996): Les Chalets d'alpage du canton de Fribourg = Die Alphütten des Kantons Fribourg. Bern.

- (2000): Hausinschriften auf dem Ballenberg. In: Jahrbuch, Schweizerisches Freilichtmuseum Ballenberg 3. Bern.

ANNELER, H. (1917): Lötschen das ist: Landes- u. Volkskunde des Lötschentales. Bern.

Antonietti, T. (1990): Das Dorf als Kulisse und Lebensraum. In: Gonseth, M.-O. (ed.): Images de la Suisse = Schauplatz Schweiz. Ethnologica Helvetica 13/14. Bern, 35-65.

Bachmann-Voegelin, F. (1984): Blatten im Lötschental. Die traditionelle Kulturlandschaft einer Berggemeinde. Bern.

Baltensweiler, W. a. Rubli, D. (1999): Dispersal: an important driving force of the cyclic population dynamics of the larch bud moth, Zeiraphera diniana Gn. In: Forest, Snow and Landscape Research 74, 3-153.

BÄTZING, W. (1993): Der sozio-ökonomische Strukturwandel des Alpenraumes im 20. Jahrhundert. Geographica Bernensia 26. Bern.

- (1996): Tourismus und nachhaltige Regionalentwicklung im Alpenraum. In: Geographische Rundschau 48, 145151.

- $\left(2003^{2}\right)$ : Die Alpen. Geschichte und Entwicklung einer Europäischen Kulturlandschaft. München.

Bellwald, I. (2000): Der Rote Segensonntag 1900. Naters.

Bellwald, I.; Kalbermatten, H. a. Bellwald, W. (1998): Archivalien, Feldzeugen und mündliche Tradition. Präliminarien zur Siedlungsgeschichte eines Alpentals. Das Beispiel Lötschen VS. In: MEyer, W. (ed.): Heidenhüttli. 25 Jahre archäologische Wüstungsforschung im schweizerischen Alpenraum. Schweizer Beiträge zur Kulturgeschichte und Archäologie des Mittelalters 23/24. Basel, 328-363.

Bellwald, I.; Kalbermatten, H. a. Büntgen, U. (2006): High elevation settlement patterns and their potential for past treeline reconstructions - Case study Lötschental. In: Mountain Research and Development (for submission).

Bellwald, W.; Buchecker, M.; Conzetti, M. a. Maurer, M. (1996): Kulturweg im Lötschental. Thun.

Beniston, M. (2003): Climatic change in mountain regions: a review of possible impacts. In: Climatic Change 59, 5-31.

Bitterli-Waldvogel, T. (1998): „Giätrich”, Wiler (Lötschen) VS 1989-1990. In: MEYER, W. (ed.): Heidenhüttli. 25 Jahre archäologische Wüstungsforschung im schweizerischen Alpenraum. Schweizer Beiträge zur Kulturgeschichte und Archäologie des Mittelalters 23/24. Basel, 174-201.

BrÁzdil, R.; Pfister, C.; WAnner, H.; StORCh, H. vON a. Luterbacher, J. (2005): Historical Climatology in Europe - State of the Art. In: Climatic Change 70, 363-430.

Buchecker, M.; Hunziker, M. a. Kienast, F. (2003): Participatory landscape development: overcoming social barriers to public involvement. In: Landscape and Urban Planning 64, 29-46. 
Büntgen, U.; Esper, J.; Schmidhalter, M.; Frank, D. C.; Treydte, K.; Neuwirth, B. a. Winiger, M. (2004): Using recent and historical larch wood to build a 1300year Valais-chronology. In: Trace 2, 85-92.

Büntgen, U.; Esper, J.; Frank, D. C.; Nicolussi, K.; Schmidhalter, M. a. Seifert, M. (2005a): The effect of power transformation on RCS - case study from 3 millennial-length alpine chronologies. In: Trace 3, $141-149$

Büntgen, U.; Esper, J.; Frank, D. C.; Nicolussi, K. a. SCHMidHALTER, M. (2005b): A 1052-year tree-ring proxy for Alpine summer temperatures. In: Climate Dynamics 25, 141-153.

Büntgen, U.; Frank, D. G.; Schmidhalter, M.; Neuwirth, B.; SeIFerT, M. a. EsPer, J. (2005c): Growth/climate response shift in a long subalpine spruce chronology. In: Trees, Structure and Function. Doi 10.1007/s00468005-0017-3.

Büntgen, U.; Frank, D. C.; Nievergelt, D. a. Esper, J. (2006): Summer temperature variations in the European Alps, AD 755-2004. In: Journal of Climate (in press).

Byers, A. C. (2000): Contemporary landscape change in the Huascarán National Park and buffer zone, Cordillera Blanca, Peru. In: Mountain Research and Development 20, 52-63.

Cook, E. R. a. Peters, K. (1981): The smoothing spline: A new approach to standardizing forest interior tree-ring width series for dendroclimatic studies. In: Tree-Ring Bulletine 41, 45-53.

- (1997): Calculating unbiased tree-ring indices for the study of climatic and environmental change. In: The Holocene 7, 361-370.

Coxeter, H. S. M. (1961): Frieze Patterns, Triangulated Polygons and Dichromatic Symmetry. In: GuY, R. K. a. WoOdrow, E. (eds.): The Lighter Side of Mathematics. New York.

De Menocal, P. B. (2001): Cultural response to climate change during the Holocene. In: Science 292, 667-672.

DitTMAnN, A. a. NüsSER, M. (2002): Siedlungsentwicklung im östlichen Hindukusch: Das Beispiel Chitral Town (North-West Frontier Province, Pakistan). In: Erdkunde 56, 60-72.

Douglass, A. E. (1929): The secret of the Southwest solved by talkative tree rings. In: National Geographic Magazine 56, 736-770.

Egloff, W. a. Egloff-Bodmer, A. (1987): Die Bauernhäuser des Kantons Wallis. Basel.

Ehlers, E. a. Kreutzmann, H. (2000): High mountain ecology and economy: potential and constrains. In: EHLERS, E. a. KReutzmann, H. (eds.): High mountain pastoralism in Northern Pakistan. Erdkundliches Wissen 132. Stuttgart, 9-36.

EsPER, J. a. GÄrTNER, H. (2001): Interpretation of tree-ring chronologies. In: Erdkunde 55, 277-288.

Esper, J.; Büntgen, U.; Frank, D. C.; Nievergelt, D. a. LiEBHOLD, A. (2006): Insect outbreak clockwork stops after 1200 years. In: Proceedings of the Royal Society, B (in review).
FISCHER, F. (1974): Waldzustandsveränderungen in einem Gebirgstal. In: Schweizerische Zeitschrift für Forstwesen 125, 906-912.

FRITTS, H. C. (1976): Tree rings and climate. London.

FurRer, B. (2003a): Bohrkerne mit Überraschungen. Neues aus der Walliser Bauernhausforschung. In: Schweizer Volkskunde 93, 79-85.

- (2003b): Kulturaustausch im ländlichen Hausbau. Inneralpin - Transalpin. Berichte über die Tagung der Regionalgruppe Alpen in Schwyz, 29. Juni - 1. Juli 2002. Beiträge zur historischen Hausforschung in den Alpen 1. Petersberg.

GRÖTZBACH, E. (1984): Mobilisierung von Arbeitskräften im Hochgebirge. Zur sozioökonomischen Integration peripherer Räume. In: GrötzBach, E. a. Rinschede, G. (eds.): Eichstätter Beiträge zur Vergleichenden Kulturgeographie der Hochgebirge. Eichstätter Beiträge 12. Regensburg, 73-91.

- (1988): High mountains as human habitats. In: AlLAN, N. J. R.; Knapp, G. W. a. Stadel, C. (eds.): Human impact on mountains. Totowa, 24-35.

Grove, J. M. (1988): The Little Ice Age. London, New York. Haberl, H.; Batterbury, S. P. J. a. Moran, E. F. (2001): Using and shaping the land: a long-term perspective. In: Land Use Policy 18, 1-8.

Haug, G. H.; Günther, D.; Peterson, L. C.; Hughen, D. M. a. Aeschlimann, B. (2003): Climate and the collapse of the Maya civilization. In: Science 299, 1731-1735.

Holmes, R. L. (1983): Computer-assisted quality control in tree-ring dating and measurements. In: Tree-Ring Bulletin 43, 69-78.

Holzhauser, H. (2002): Dendrochronologische Auswertung fossiler Hölzer zur Rekonstruktion der nacheiszeitlichen Gletschergeschichte. In: Schweizerische Zeitschrift für Forstwesen 153, 17-28.

Huber, S.; Sieber, R. a. WiPf, A. (2003): Multimedia in der Gebirgskartographie - 3D-Anwendungen aus dem ,Atlas der Schweiz - interaktiv 2'. In: Kartographische Nachrichten 5, 217-224.

Hunziker, M. a. Kienast, F. (1999): Potential impacts of changing agricultural activities on scenic beaity - a prototypical technique for automated rapid assessment. In: Landscape Ecology 14, 161-176.

IPCG (INTERGOVERNMENTAL PANEL ON GLIMATE CHANGE) (2000): Land use, land-use change, and forestry. Special Report. Cambridge.

Kalbermatten, H. a. Kalbermatten, L. (1997): Blatten. Was alte Menschen, alte Häuser und Schriften erzählen. Arlesheim.

KANTON WALLIS (2003): Das Wallis in Zahlen. Sion.

KeIler, M.; ZischG, A.; Fuchs, S.; Hama, M. a. StÖtter, J. (2005): Avalanche related damage potential - changes of persons and mobile values since the mid-twentieth century, case study Galtür. In: Natural Hazards and Earth System Sciences 5, 49-58.

KienAST, F. (1993): Analysis of historic landscape patterns with a Geographic Information System: a methodological outline. In: Landscape Ecology 8, 103-118. 
Krausmann, F.; Haberl, H.; Schulz, N. B.; Erb, K.-H.; Darge, E. a. Gaube, V. (2003): Land-use change and socio-economic metabolism in Austria - Part I: driving forces of land-use change: 1950-1995. In: Land Use Policy 20, 1-20.

LAMB, H. H. (1965): The early medieval warm epoch and its sequel. In: Palaeogeography, Palaeoclimatology, Palaeoecology 1, 13-37.

Lambin, E. F.; Turner, B. L.; Geist, H. J.; Agbola, S.; Angelsen, A.; Bruce, J. W.; Coomes, O.; Dirzo, R.; Fischer, G.; Folke, C.; George, P. S.; Homewood, K.; Imernon, J.; Leemans, R.; Li, X.; Moran, E. F.; MortiMORE, M.; Ramakrishnan, P. S.; Richards, J. F.; Skanes, H.; Steffen, W.; Stone, G. D.; Svedin, U.; Veldkamp, T.; Vogel, C. a. XU, J. (2001): The causes of land-use and land-cover change: moving beyond the myths. In: Global Environmental Change 11, 261-269.

LeibundGut, H. (1938): Wald- und Wirtschaftsstudien im Lötschental. Bern.

Lichtenberger, E. (1979): Die Sukzession von Agrar- zur Freizeitgesellschaft in den Hochgebirgen Europas. In: Haimayer, P.; Meusburger, P. a. Penz, H. (eds.): Fragen geographischer Forschung. Leidlmair-Festschrift. 1. Innsbrucker Geographische Studien 5. Innsbruck, 401-436.

Magny, M. (2004): Holocene climate variability as reflected by mid-European lake-level fluctuations and its probable impact on prehistoric human settlement. In: Quaternary International 113, 65-79.

MaIse, C. (1998): Archäoklimatologie. Vom Einfluss nacheiszeitlicher Klimavariabilität in der Ur- und Frühgeschichte. In: Jahrbuch der Schweizerischen Gesellschaft für Ur- und Frühgeschichte 81, 197-235.

Mathieu, J. (2003): The Mountains in Urban Development. Lessons from a comparative view. In: BUSSER, T.; LORENZetTi, L. a. Mathieu, J. (red.): Andes - Himalaya Alpes $=$ Anden - Himalaja - Alpen. Histoire des Alpes 8. Zürich, 15-35.

Neuwirth, B.; Esper, J.; Schweingruber, F. H. a. Winiger, M. (2004): Site ecological differences to the climatic forcing of spruce pointer years from the Lötschental, Switzerland. In: Dendrochronologia 21, 69-78.

Niederer, A. (1993): Alpine Alltagskultur zwischen Beharrung und Wandel. Ausgewählte Arbeiten aus den Jahren 1956 bis 1991. Bern, Stuttgart, Wien.

Nüsser, M. (2000): Change and persistence: Contemporary landscape transformation in the Nanga Parbat Region, Northern Pakistan. In: Mountain Research and Development 20, 348-355.

- (2001): Understanding cultural landscape transformation: A re-photographic survey in Chitral, Eastern Hindukush, Pakistan. In: Landscape and Urban Planning 57, 241-255.

- (2003): Ressourcennutzung und Umweltdegradation: Mensch-Umwelt-Beziehungen in peripheren Gebirgsräumen. In: Meusburger, P. a. Schwan, T. (eds.): Humanökologie. Ansätze zur Überwindung der Natur-Kultur-Dichotomie. Erdkundliches Wissen 135. Stuttgart, 327-342.

Obrecht, J.; Meyer, W. a. Reding, G. (2003): Hochalpiner Siedlungsplatz Müllerenhütte, Melchsee - Frutt. Bericht über die archäologische Untersuchung 1997. In: FURRER, B. (ed.): Kulturaustausch im Ländlichen Hausbau. Inneralpin - Transalpin. Berichte über die Tagung der Regionalgruppe Alpen in Schwyz, 29. Juni - 1. Juli 2002. Beiträge zur historischen Hausforschung in den Alpen 1. Petersberg.

Olsson, E.; Austrheim, G. a. Grenne, S. N. (2000): Landscape change patterns in mountain, land use and environmental diversity, Mid-Norway 1960-1993. In: Landscape Ecology 15, 155-170.

OтT, E. (1978): Über die Abhängigkeit des Radialzuwachses und der Oberhöhen bei Fichte und Lärche von der Meereshöhe und Exposition im Lötschental. In: Schweizerische Zeitschrift für Forstwesen 3, 169-193.

Parmenter, A. W.; Hansen, A.; Kennedy, R. E.; Cohen, W.; Langner, U.; Lawrence, R.; Maxwell, B.; Gallant, A. a. Aspinall, R. (2003): Land use and land cover change in the Greater Yellowstone ecosystem: 1975-1995. In: Ecological Applications 13, 687-703.

Paulsen, J. a. Körner, C. (2001): GIS-analysis of treeline elevation in the Swiss Alps suggests no exposure effect. In: Journal of Vegetation Science 12, 817-824.

Pfister, C. (1999): Wetternachhersage. 500 Jahre Klimavariationen und Naturkatastrophen 1496-1995. Bern, Stuttgart, Wien.

Price, L. W. (1981): Mountains and man. A study of process and environment. Berkley, Los Angeles, London.

RAGAZ, G. (1991): Maiensässen erhalten oder zerfallen lassen? In: BBV-Information 11, 34.

Raible, C. C.; Casty, C.; Luterbacher, J.; Pauling, A.; Esper, J.; Frank, D. C.; Büntgen, U.; Roesch, A. G.; Tschuck, P.; Wild, M.; VidAle, P. L.; Schär, C. a. WANNER, H. (2006): Climate variability - observations, reconstructions, and model simulations for the Atlantic-European and Alpine region from 1500-2100 AD. In: Climatic Change (in press).

Rhoades, R. E. a. Thompson, S. I. (1975): Adaptive strategies in alpine environments: beyond ecological particularism. In: American Ethnologist 2, 535-551.

Risch, A. G.; SchÜtz, M.; KRÜsi, O.; Kienast, F.; Wildi, O. a. Bugmann, H. (2004): Detecting successional changes in long-term empirical data from subalpine conifer forests. In: Plant Ecology 172, 95-105.

Ruppen, W. (1976): Der Bezirk Östlich-Raron. Die Kunstdenkmäler des Wallis 1. Basel.

- (1979): Das Untergoms. Die Kunstdenkmäler des Wallis 2. Basel.

- (1991): Das Obergoms. Die Kunstdenkmäler des Wallis 3. Basel.

Schmidt, B.; Köhren-Jansen, H. u. Freckmann, K. (2001): Auf den Spuren alter Häuser. Marburg.

Schweingruber, F. H. (1996): Tree rings and environment dendrochronology. Bern.

- (2001): Dendroökologische Holzanatomie. Anatomische Grundlagen der Dendrochronologie. Bern

Siegen, J. (19909): Lötschental. Ein Führer für Touristen. Lausanne. Franz. Erstausg. Lausanne 1923. Dt. Erstaufl. 1929. 
Stebler, F. G. (1907): Am Lötschberg. Land und Volk von Lötschen. Zürich. Reprint 1981.

- (1921): Die Vispertaler Sonnenberge. In: Jahrbuch des Schweizer Alpenclub 56, 1-144.

Tinner, W.; Lotter, A. F.; Ammann, B.; Condera, M.; Hubschmid, P.; van Leeunen, J. F. N. a. Wherli, M. (2003): Climatic change and contemporaneous land-use phases north and south of the Alps 2300 BC to 800 AD. In: Quaternary Science Reviews 22, 1447-1460.

Treydte, K.; Schleser, G. H.; Schweingruber, F. H. a. WINIGER, M. (2001): The climatic significance of $\delta 13^{\mathrm{C}}$ in subalpine spruces (Lötschental/Swiss Alps). A case study with respect to altitude, exposure and soil moisture. In: Tellus-B 53, 593-611.

Turner, M. G. (1990): Spatial and temporal analysis of landscape patterns. In: Landscape Ecology 4, 21-30.

Turner, B. L. a. Meyer, W. B. (1994): Global land use and land cover change. An overview. In: Meyer, W. B. a. TuRNER, B. L. (eds.): Changes in land use and land cover: A global perspective. Cambridge, 3-10.

Turner, B. L.; Meyer, W. B. a. Skole, D. L. (1994): Global land use and land cover change: towards an integrated study. In: Ambio 23, 91-95.

Turner, M. G.; Wear, D. N. a. Flamm, R. O. (1996): Land ownership and land-cover change in the southern Appalachian highlands and the Olympic Peninsula. In: Ecological Applications 6, 150-172.

Uhlig, H. (1995): Persistence and change in high mountain agricultural systems. In: Mountain Research and Development 15, 199-212.

Wanner, H.; Holzhauser, H.; Pfister, C. a. Zumbühl, H. (2000a): Interannual to century scale climate variability in the European Alps. In: Erdkunde 54, 62-69.
Wanner, H.; Luterbacher, J.; Gyalistras, D.; Rickli, R.; Salvisberg, E. a. Schmutz, C. (2000b): Klimawandel im Schweizer Alpenraum. Zürich.

WeIss, R. (1959): Häuser und Landschaften der Schweiz. Erlenbach, Zürich.

Wigley, T.; Briffa, K. R. a. Jones, P. D. (1984): On the average of value of correlated time series, with applications in dendroclimatology and hydrometeorology. In: Journal of Climatology and Applied Meteorology 23, 201-213.

Wilson, R. J. S.; Luckmann, B. H. a. Esper, J. (2004): Utilizing historical tree-ring data for dendroclimatology: a case study from the Bavarian Forest, Germany. In: Dendrochronologia 21, 53-68.

- (2005): A 500 year dendroclimatic reconstruction of spring-summer precipitation from the lower Bavarian Forest region, Germany. In: International Journal of Climatology 25, 611-630.

Winiger, M. (1996): Karakorum im Wandel. Ein methodischer Beitrag zur Erfassung der Landschaftsdynamik in Hochgebirgen. In: Hurni, H.; Kienholz, H.; Wanner, H. a. Wiesmann, U. (eds.): Umwelt-Mensch-Gebirge. Beiträge zur Dynamik von Natur- und Lebensraum. Festschrift B. Messerli. Jahrbuch der Geographischen Gesellschaft Bern 59. Bern, 59-74.

WINIGER, M. a. BÖRST, U. (2003): Landschaftsentwicklung und Landschaftsbewertung im Hochgebirge. Bagrot (Karakorum) und Lötschental (Berner Alpen) im Vergleich. In: Wiesmann, U.; Jeanneret, F.; Schwyn, M. a. WASTL-Walter, D. (eds.): Welt der Alpen - Gebirge der Welt : Ressourcen, Akteure, Perspektiven. Bern, 45-59. 